\title{
Potential petroleum sources of deep Paleozoic marine reservoirs in the Tarim Basin, NW China: Exploration prospect implication
}

\author{
JIN ZHIJUN ${ }^{1,2 *}$ ZHANG SHUICHANG $^{3}$ LIU QUANYOU $^{1,2}$ \\ SU JIN ${ }^{3}$ \\ ${ }^{1}$ State Key Laboratory of Shale Oil and Gas Enrichment \\ Mechanisms and Effective Development \\ ${ }^{2}$ SINOPEC Petroleum Expol. \& Prod. Research Institute \\ ${ }^{3}$ CNPC Research Institute of Petroleum Expol. \& Dev. \\ *corresponding author: jinzj.syky@sinopec.com
}

The Tarim Basin, with an area of about $560 \times 10^{3} \mathrm{~km}^{2}$, was the biggest marine petroliferous basin in China. The depth of petroleum explorated in Palaeozoic craton is more than $7 \mathrm{~km}$ so far, invovling the Shunbei oilfield and Yueman oildfield. The main pays are Ordovician carbonates. Particularly, the deepest marine reservoir with the depth of $8480 \mathrm{~m}$ (Well Luntan-1) is currently discovered in Lower Cambrian of Tabei uplift. Various petroleum resources was developed from plateform slope and margine to the paleouplift in the Palaeozoic craton, involving dry gas through to condensate, light, normal, waxy and heavy oils to solid bitumen. However, Oil-source correlation of complex hydrocarbons in the Tarim Craton has long been controversial. Multiple tectonic movements and multiple generation, migration processes and secondary alteration are generally presumed to have caused physico-chemical changes and make the oil-source correlation complicated.

We analyzed the biomarkers and carbon isotope of the hydrocarbons and calssic source rocks in the major reservoirs and deep carbonate strata of the Tarim Basin. Results show the marine petroleum is a mixture from the Cambrian and Ordovician source rocks, with increasing contribution of the Cambrian source rocks in the both southern- northern slopes of the Majiaer depression. Considering the lithology and sedimentary facies data, the spatial distribution of the Cambrian and Ordovician source rocks was reconstructed on the basis of seismic reflection characteristics, and highquality source rocks were revealed to be mainly located in the slope belt of the basin and were longitudinally developed over the maximum flooding surface during the progressiveregressive cycle. Affected by the transformation of the tectonic framework in the basin, the overlays of source rocks in different regions are different and the distribution of oil and gas was determined by the initial basin sedimentary structure and later reformation process. It is suggested that the northern slope of the Central Uplift-Shuntuo-Gucheng areas would be a recent important target for oil and gas exploration. 